\title{
PERCEPTION OF COMMERCIAL AND SOCIAL ADVERTISING BY GENERATION Y IN THE CZECH REPUBLIC
}

\author{
Ivana Bulanda ${ }^{1, a}$, Zdenka Kádekováa,b,, , Ingrida Košičiarováa ${ }^{3, c}$ and Vladimír \\ Vavrečka ${ }^{4, \mathrm{~d}}$ \\ ${ }^{1}$ University of Entrepreneurship and Law, Department of Marketing, Vltavská 585/14, Prague 150 00, \\ Czech Republic \\ ${ }^{2}$ Slovak University of Agriculture in Nitra, Faculty of Economics and Management, Department of \\ Marketing and Trade, Tr. A. Hlinku 2, Nitra 949 76, Slovak Republic \\ ${ }^{3}$ Slovak University of Agriculture in Nitra, Faculty of Economics and Management, Department of \\ Marketing and Trade, Tr. A. Hlinku 2, Nitra 949 76, Slovak Republic \\ ${ }^{4}$ University of Entrepreneurship and Law, Department of Marketing, Vltavská 585/14, Prague 15000 , \\ Czech Republic \\ aivana.bulanda@vspp.cz, zdenka.kadekova@uniag.sk ${ }^{\mathrm{b}}$, ingrida.kosiciarova@uniag.sk ${ }^{\mathrm{c}}$, \\ vladimir.vavrecka@vspp.cz ${ }^{\mathrm{d}}$ \\ ${ }^{*}$ Corresponding authors
}

Cite as: Bulanda, I., Kádeková, Z, Košičiarová, I., Vavrečka, V. (2020). The perception of commercial and social advertising by the generation $Y$ in the Czech Republic, Ekonomicko-manazerske spektrum, 14(2), 63-77.

Available at: dx.doi.org/10.26552/ems.2020.2.63-77.

Received: 6 June 2020; Received in revised form: 20 August 2020; Accepted: 12 September 2020; Available online: 27 November 2020

\begin{abstract}
Advertising as the dominant tool of marketing management and marketing communication has become an inextricable part of culture and society. Its influence significantly affects its immediate surroundings. The current period, characterized by a communication boom, allows for a more aggressive application of advertising in public contexts as well as in managerial solutions. Advertising thus penetrates all aspects of life and its setup can be found in both commercial and non-commercial spheres. Thanks to perception, advertising becomes an incentive that stimulates purchase of products, services, but also ideas. Perception reflects reality through the sense organs, and each instance of perception is complemented by subjective factors, a process linked to past experiences. The study presents partial results of research that examined perception of commercial and social advertising by the Generation Y customer segment in the Czech Republic. The research used the method of data collection by questionnaire with implementation of the semantic differential method with a seven-point rating scale to find out what denotative and connotative meanings Generation $\mathrm{Y}$ respondents attach to the terms commercial and social advertising. The research data were processed using descriptive and inferential statistics. The resulting findings are related to perception of the terms commercial and social advertising by the examined Generation Y group in their semantic space. The findings show that the concept of commercial advertising is perceived in predominantly negative connotations for the entire research group, and to absence of distinction on their part between the terms commercial and social advertising.
\end{abstract}


Perception of commercial and social advertising

by generation $Y$ in the Czech Republic

Authors: Ivana Bulanda, Zdenka Kádeková,

Ingrida Košičiarová, Vladimír Vavrečka

Keywords: perception, generation Y, commercial advertising, social advertising, semantic differential, marketing management

JEL Classification: M3, M31, M37

\section{Introduction}

Due to globalization and market openness, economic and distribution conditions, as well as promotional conditions (forms of attracting and reaching potential customers) are changing, which results in strong competition and increasingly challenging conditions in the fields of consumption and sales of products and services (Horska et al., 2020; Kubicova et al., 2017; Smutka et al., 2016). The current form of modern marketing predicts the emphasis on strategic importance of marketing communication. Awareness of promoted products or services exists in the minds of individual customer groups not only due to their experience with them, but especially due to the long-term effects of interactive stimuli. Advertising as a dominant tool of marketing communication has become an inextricable part of culture and society (Bulanda and Vavrecka, 2019a). It is a part, product, and at the same time a reflection of culture, guided by social conventions and ideas. Through communication stimuli, it is one of the participants involved in the dissemination of information, creation of ideas, value systems, attitudes, or personal identity of the individual (Zelinsky and Bulanda, 2019; Herbus, 2016). It is also a longterm integral part of business life (Nagyova et al., 2018). Advertising is often considered a synonym for marketing communication, as it is, in addition to personal sales, direct marketing, public relations or sales support, its most visible tool (Svetlik, 2018; Mikulas and Svetlik, 2016). It is the only one of the said activities to use the mass media in both their traditional (newspapers, radio, television) (Lincenyi, 2013) and modern form (the internet, social media) to spread the marketing message (Kadekova and Holiencinova, 2018), while technological development brings with it new advertising media in shorter and shorter time intervals (Nagyova et al., 2019). Modern advertising provides information about the outside world; presents and conveys the values of the company which distributes it. It sets out the criteria for forms of socio-political activity as well as iconic models, which usually become cultural paradigms of society. It can be considered one of the most controversial phenomena, as it has become entangled in all aspects of social activities as an inseparable fragment of reality, occupying an important place in the infrastructure of modern media and marketing communication. However, in the form of social advertising, it has moved into the broader context of social relations. It thus went beyond the use of simple advertising techniques limited to commercial promotion of products or services. It ventured into the realm of social persuasion, and its established rhetorical categories became ubiquitous in the contemporary social discourse. In recent years, social advertising has become increasingly established in the communication activities of social entities with both commercial and non-commercial focus and mission; it has become a distinctive category of marketing communication. Although social advertising is species-specific, it is still considered advertising. The general valid principles of commercial advertising are therefore to some extent applicable in social advertising, where the effort to influence the recipient is constant. In view of the above, it makes sense to address perception of these types of unique communication tools by customer segments. The specifics of social advertising call for the study of this phenomenon emerging in the field of marketing communication, whereby the long overlooked social potential of advertising and its impact on society represents a relevant new field of scientific research (Bulanda, 2017). 


\section{Literature review}

\section{Common Attributes of Commercial and Social Advertising as a Part of Marketing Management}

When comparing the structural and functional elements of commercial and social advertising, we discover common as well as differing determinants. Although social advertising serves different purposes, is addressed to different audiences, uses different means, certain general principles of effective communication remain the same. This is because the principles of advertising are based on universal natural laws related to cognitive processes, emotions, and motivation of beneficiaries (Matuszewska, 2013). In essence, the common features of commercial and social advertising within marketing management can be identified from several related definitions of these terms. We will start with the most frequently cited definition of advertising by the American Marketing Association: "Advertising is any paid form of impersonal presentation and offer of ideas, goods or services through an identifiable sponsor" (Vysekalova et al., 2012, p. 20). A connection to this definition of advertising is found in several authors (Jankova, 2015; Kotler and Armstrong, 2016; Svetlik, 2018). We also note it in M. Barańska's (2011, p. 24) claim that advertising is one of the forms of paid marketing presentation, in accordance with the law and good morals, implemented to maintain or increase demand for products and services, which affects the potential decision of buyers through the mass media and other means of communication in a manner organized in the interest of the advertiser". Emphasizing that advertising is organized in time and is a deliberate, planned deployment of promotional funds to achieve turnover is found in M. Fabus et al. (2011). A more critical but undeniably stimulating view of advertising is provided by R. A. Bauer and S. A. Greyer (1968, in Frankovsky and Birknerova, 2016), who specified the economic and social clusters including basic scaling of opinions and beliefs about advertising. The economic cluster involves the belief that the items are necessary, help to raise living standards, while advertising results in better products for the public as well as lower prices. The social cluster involves the belief that advertising is a true picture of the product, insulting the intelligence of the average consumer and convincing people to buy things they not really want to buy. A more specific approach to the definition of advertising is found in L. Faltanova (1997), where it is mentioned that advertising in addition to promotion of products, activities, and services, can from some points of view be a broad source of information that reveal the developmental, cultural, and social aspects of a particular phenomenon displayed. Some current authors therefore define advertising even more specifically: as a socio-cultural phenomenon, a compiler of social meanings, values, norms, and patterns of behavior (Gerus, 2014), which is an important feature of consumer culture (Walotek-Ściańska, 2010). According to M. Zelinsky and Bulanda (2019), product advertising culture is guided by the existing social norms and rules, making use of stereotypes and prejudices, while on the other hand, it is gradually changing and redefining them. The basic condition for effective advertising is transformation of creative ideas, in which it is necessary to pay great attention to the selection of appropriate techniques (Svetlik, 2011). These definitions suggest that the essence of commercial advertising is to activate sales by informing the public about the emergence of a new product on the market or the possibility of (using) a service, promoting a product or service, encouraging the use of a proposed offer and presenting it in a way that the target group thinks is better than the competing offer. This means that the goal of commercial advertising is to maintain, acquire or expand individual groups of the customer spectrum for the purpose of economic profit. At the same time, the entity as the sender of commercial messages must distribute advertising content in accordance with the applicable laws and social standards in the society. 
Perception of commercial and social advertising

by generation $Y$ in the Czech Republic

Authors: Ivana Bulanda, Zdenka Kádeková,

Ingrida Košičiarová, Vladimír Vavrečka

Likewise, social advertising within marketing management is obliged to comply with the established laws and social norms, more so as its goal is oriented towards a certain ideological gain. The content of reports with social advertising focuses on the promotion of prosocial attitudes and behavior, informs about social problems, and draws attention to the possibilities of their solution. The common denominator of commercial and social advertising is that they aim to distribute advertising content to the public and motivate it to become interested in the subject of advertising. Other common attributes identifiable when comparing commercial and social advertising include that both forms of advertising:

- plan promotional activities,

- have a sender,

- are targeted at a specific target group,

- are disseminated through the mass media,

- apply the principles of creativity.

We consider the mechanism of persuasive action of social advertising, similar to its counterpart in commercial advertising, to be a fundamental common attribute. In essence, it is an effort to achieve a form of persuasive effect on the recipient, i.e., an activation and setting identical with the focus of the message (Vopalenska, 2011). It takes the form of intentional or unforced influence, while in the context of the advertising process itself it should be emphasized that it is a form of mental influence that consciously uses a certain procedure that gives rise to voluntary acceptance, self-fulfillment, and further concern. The subject of both forms of advertising (Frankovsky and Birknerova, 2016), the recipient, is thus granted and retains the autonomy of self-perception, as a free-thinking and independently deciding being, able to assess the truthfulness or deception of advertising arguments, claims, etc. (Vopalenska, 2011). The functioning of individual elements and relationships in the persuasive process is based on the same means of expression as commercial and social advertising (Koskova and Koprda, 2015; Bulanda, 2017).

Differences Between Commercial and Social Advertising within Marketing Management

Commercial and social advertising within marketing management form an integral part of a more complex set of marketing activities. Due to the growing effectiveness of their persuasion techniques, they have become the basis of social discourse, given the power of their coverage extended throughout society (Gerus, 2014). Despite the common intersections in the attributes described above, it is necessary to reflect the determinants of the fundamental differences forming the dividing line between them. In determining them, we can rely on a more critical view of the phenomenon of advertising as such. Critics (Kendrick et al., 2013) accuse advertising of manipulating people; creating and inciting false needs and values that promote materialism; perpetuating stereotypes; and presenting a personal world that is protected from social problems. Although there is some validity in these criticisms, it can be objectively admitted that most commercial advertisements depict a fantasy, an idealized world structured around the consumption of products or services. This is pointed out by several authors (Jankova and Runnova, 2017), especially R. W. Pollay (Kendrick et al., 2013), who discussed the wide range of harmful effects of advertising on society. Criticism has been directed at the promotion of commercialism, intrusiveness, and irrationality; strengthening of social stereotypes; and trivializing of language. From a marketing standpoint, commercial advertising is one of the techniques that allows the flow of economic information offered on demand (Dourado, 2017). Thus, in the sum of the key differences between social and commercial advertising, one of the main determinants will be the presence or absence of an economic, commercial goal-profit (Kim and $\mathrm{Yu}, 2015$ ). This attribute, together with the conscious attempt to replace the 
imagination of consumption with social commentary, violates the fundamental structural norms of advertising in the commercial sense (Sandikci, 2011). Social advertising, as a part of marketing management, has since its inception been a factor in creating or modifying social change. Social advertising is referred to in a wide range of word equivalents as "non-profit, charitable or pro bono advertising" (Bulanda and Vavrecka, 2019a). From the point of view of the American Marketing Association (AMA), social advertising is intended to educate and motivate the target group in the implementation of socially desirable measures. It calls for prosocial behavior or abandonment of unwanted behavior. It provides specific information that negates social concerns and prejudices, making the recipient of these messages more aware of their social (community) role and responsibility, not only for themselves but also for other people. It is a part of the social and cultural environment, representing a process of persuasive communication, the main aim of which is to evoke socially desirable attitudes or behavior (Maison and Wasilewski, 2008). The reality displayed in social advertising contrasts with commercial advertising. Social advertising is an important element of experiencing social reality. It is a direct reflection of social values, humanistic relations between people, the level of cultural development of society (Nureeva, 2015). It covers a range of difficult topics related to, among other things: human intimacy, moral decisions, individual behavior (illness, addiction, tolerance, violence, prejudice, racism, war, environmental protection, road safety, etc.) (Zelinsky et al., 2018). The fundamental determinant of the difference between social and commercial advertising will therefore be the goal orientation itself, from which further specification of the different attributes will be derived. Their summary can be found in several authors (Szwajca, 2015, Herbus, 2016; Koter and Armstrong, 2016) (Tab. 1).

Table 1: Comparison of commercial advertising and social advertising

\begin{tabular}{|c|c|c|}
\hline & Commercial Advertising & Social Advertising \\
\hline Goals & $\begin{array}{l}\text { product sales, improving brand and } \\
\text { company awareness, gaining a larger } \\
\text { group of customers }\end{array}$ & $\begin{array}{l}\text { raise awareness of the public or } \\
\text { its groups and develop certain } \\
\text { socially desirable attitudes; and } \\
\text { behaviour }\end{array}$ \\
\hline Sender's intention & $\begin{array}{l}\text { desire for profit - limiting the confidence } \\
\text { of the buyer or the absence of trust }\end{array}$ & $\begin{array}{l}\text { desire to help others - great trust } \\
\text { in the sender }\end{array}$ \\
\hline Benefits of the beneficiary & $\begin{array}{l}\text { it benefits the individual immediately or } \\
\text { in a short time }\end{array}$ & $\begin{array}{l}\text { in the long run or not benefiting a } \\
\text { directly specified individual }\end{array}$ \\
\hline $\begin{array}{l}\text { Complexity of change of beneficiary's } \\
\text { position (strength, durability and } \\
\text { stability of attitude) }\end{array}$ & $\begin{array}{l}\text { generally low, insignificant and shallow } \\
\text { change of attitude linked to consumer } \\
\text { behaviour, e.g. change the brand of the } \\
\text { selected product }\end{array}$ & $\begin{array}{l}\text { generally high, often substantial } \\
\text { and profound change of attitude } \\
\text { or resignation from certain } \\
\text { actions, which can be dangerous, } \\
\text { for example }\end{array}$ \\
\hline Character of the report & $\begin{array}{l}\text { usually very pleasant, evoking positive } \\
\text { emotions }\end{array}$ & \\
\hline Budget & $\begin{array}{l}\text { usually high or very high (depending on } \\
\text { the type of ad) }\end{array}$ & \\
\hline
\end{tabular}

D. Maison and N. Maliszewski (2008) compare both types of advertisements. They focus their attention on the five levels on which specific differences between social and commercial advertising develop. To these five levels of differences between social and commercial advertising, D. Doliński (2010) assigns two more, namely the advertising environment and the way of "accepting advertising by the target group", which is independent and places them as separate categories of differences between social and commercial advertising. 
Perception of commercial and social advertising

by generation $Y$ in the Czech Republic

Authors: Ivana Bulanda, Zdenka Kádeková,

Ingrida Košičiarová, Vladimír Vavrečka

\section{The Generation Y Customer Segment}

Generational differences have been the subject of many scientific studies in the recent years (e.g., Kosiciarova et al., 2020; Rybanska et al., 2019; Sedik, Horska et al., 2018; Sedik, Knazovicka et al., 2018; Rybanska et al., 2015, etc.). It is possible to identify this subject of research in academic literature related to various fields of humanities and social sciences. This involves marketing communication, too, which is currently focused on targeted addressing of defined customer segments (Bulanda and Vavrecka, 2019b). In general, the term generation can be defined from several perspectives. For the field of marketing communication, a sociological definition is essential, which represents a generation as a set of people born in a certain period, regardless of kinship, which is connected not only by age but also by socialization, having grown up in similar historical and cultural conditions. J. Herbold and B. Douma (2013) suggest that the historic event of Generation Y is the digital revolution, which is linked to technological innovation and change. The term "Generation Y" originated in the 1990s. The term was first used in August 1993 in the American magazine Advertising Age, in an article describing the then teenagers. It drew attention to the modern definition of a young adolescent group of customers which differed markedly from the previous demographic segments (the baby boomers, Generation X) (Acar, 2014).

To date, there is no consensus on defining the age range of Generation Y. In the broadest sense, it includes individuals born between 1977 and 2002 (Behrstock and Clifford, 2009). However, J.W. Smith (In: Paul, 2001) points out that such a "rough generation definition makes no sense" because the most effective way to achieve the effectiveness of addressing it is to differentiate it into three partial segments, emphasizing the view of Generation $\mathrm{Y}$ in the dimensionality of three age groups. Several authors (Svetlik, 2018; Bulanda and Vavrecka, 2019) describe Generation Y as individualistic, educated, technically literate, sophisticated, mature, and ethnically diverse. Given the current findings mapping Generation Y, we can start from the concept presented by Baran and Kłos (2014). It reflects the issue of positive and negative aspects of specific characteristics in Generation Y (Table 2).

Table 2: Generation Y profiling

\begin{tabular}{ll}
\hline \multicolumn{1}{c}{ Positive aspects } & \multicolumn{1}{c}{ Negative aspects } \\
\hline $\begin{array}{l}\text { positive approach to work } \\
\text { independence and ambition }\end{array}$ & $\begin{array}{l}\text { unwillingness to comply with the rules } \\
\text { demanding attitude towards the employer } \\
\text { difficulties in direct contact - communication (preference } \\
\text { for electronic communication) }\end{array}$ \\
positive attitude towards change and innovation & problem of accepting criticism \\
high self-confidence & willingness to take risks \\
clear definition of expectations & lack of consequences, self-discipline \\
preference for teamwork & unrealistic expectations \\
care for work-life balance & lack of patience \\
ease of searching and finding information & bad work ethic \\
the ease of establishing global interaction & difficulties in resolving everyday conflicts \\
establishing multicultural contacts & the need for feedback and stimulation \\
simple and frequent communication between peers & bad interpersonal skills in teamwork with future \\
generations - intergenerational conflict
\end{tabular}


The massive maturation of this demographic customer segment growing up in a globalized society with "unrestricted opportunities" is closely linked to the dynamic development of information and communication technologies. Members of Generation Y are intimately familiar with the internet as a source of information. When searching for data, they prefer simplicity, speed, and immediate availability (Yagerova, 2012). Texts with which they are confronted are mostly "scanned" rather than read, they are used to performing several activities or tasks at once - the so-called multitasking. They see communication as their domain and seek it intensively. However, their weak ability to concentrate presents a problem (Lonska, 2014). They rapidly adopt new communication platforms that have a significant impact on how Generation $\mathrm{Y}$ communicates (with friends, peers, strangers) as they provide them with 24-hour access to information (Bolton et al., 2013). As stated by L. Bakos (2014), they prefer fast and immediate answers and therefore prefer the electronic form of communication. The Generation $Y$ phenomenon can be reflected from several points of view. In recent years, the focus of empirical research in this area has been on research of the generation's properties and values, which are compared with the characteristics of previous generations (Polakevicova et al., 2014; Kosiciarova et al, 2020).

\section{Methodology}

The study presents partial results of the research project "Value Orientation of Customer Segments in the Czech Republic" (GA / 2019/13). Overall, the project is focused on several generations of customer segments, and in the present paper we provide partial outputs that relate to respondents from Generation Y. It reflects findings regarding perception of social and commercial advertising by the Generation Y customer segment in the Czech Republic. The main goal of the study was to examine subjective perception of the terms commercial and social advertising in the Generation Y customer segment in the Czech Republic.

In terms of setting the main goal, we formulated the following research questions (RQ) and one hypothesis $(\mathrm{H})$ :

RQ1: How is the concept of commercial advertising perceived in the examined group of the Generation Y customer segment?

RQ2: How is the concept of social advertising perceived in the examined group of the Generation Y customer segment?

RQ3: Are there differences in perception of the terms social and commercial advertising in the examined group of the Generation Y customer segment?

$\mathrm{H}$ : We assume that in the examined set of the Generation Y customer segment, there is a correlation between perception of the term commercial advertising and perception of the term social advertising.

The research group consisted of 100 respondents, of which $52 \%$ were women $(\mathrm{N}=52)$ and $48 \%$ men $(\mathrm{N}=48)$. The average age of the whole research group was 37.93 years. The average age of women was 40.03 years. The average age of men was 35.64 years. There was a higher representation of women in the research group. The disproportionate nature of the research population in terms of gender representation can be explained by the fact that it could be influenced by a determinant related to the current demographic structure of the femaledominated population. Nevertheless, we can state that the research set corresponds to the specified criterion of intentional selection with regard to the segmentation approach of the generational typology and represents the customer segment of Generation Y. 
Perception of commercial and social advertising

by generation $Y$ in the Czech Republic Authors: Ivana Bulanda, Zdenka Kádeková, Ingrida Košičiarová, Vladimír Vavrečka

The research was conducted by targeting respondents through an e-questionnaire, which was distributed by email and through closed student social e-groups. In terms of socio-demographic characteristics of respondents, we found out their highest level of education. The results showed that sixty-four respondents completed tertiary education and thirty-six respondents completed secondary education. The primary method of data collection was the questionnaire method with implementation of the secondary semantic differential method. The authors of the semantic differential method are Osgood, Suci, and Tannenbaum. As originally introduced, the method was developed to measure the connotative meaning of concepts, later its use has spread in the humanities and social sciences in the study of social perception, mental and social representations. At present, this method has also found its application in the field of marketing research, being used in market research and public opinion polling. Its modified applications for measuring attitudes and frequent use of evaluation scales in marketing research are also widespread. The semantic differential method consists of stimuli, most often concepts and scales on which these concepts are evaluated. One of the main features of the semantic differential is the stimuli whose semantic space we want to find out. The most common stimuli are words, representing concepts that are key to a particular research problem.

The scales are determined empirically and are formed by two bipolar adjectives that serve as anchors at both ends of the scale. The scales have five or seven points, with seven-point scales used mostly in marketing research. In the scales' background are three dominant dimensions of factors - evaluation, potency (strength), and activity. In our research, we applied a semantic differential with a seven-point scale (the higher the number, the stronger the inclination toward a negative adjective) which consisted of thirty-six pairs of bipolar adjectives, focusing on the three basic dimensions of the semantic differential, also referred to as EPA (evaluation, potency, and activity). We used the following pairs of bipolar adjectives in the research: 1. good-bad, 2. important-insignificant, 3. understanding-moralizing, 4. tolerantintolerant, 5. exclusive-ordinary, 6. rich-poor, 7. contemplative-shallow, 8. public-private, 9. sincere-false, 10. friendly-unfriendly, 11. tractable-intractable, 12. natural-artificial, 13. sureuncertain, 14. honest-unprincipled, 15. reliable-doubtful, 16 liberal-authoritative, 17. engaging-boring, 18. strong-weak, 19. simple-complex, 20. organized-chaotic, 21. gentlerough, 22. naive-calculating, 23. tranquil-excited, 24. loud-quiet, 25. trustworthy-misleading, 26. protecting-non-protective, 27 . devoted-egotistic, 28 . socially beneficial-socially unhelpful, 29. practical-impractical, 30. commercial-non-commercial, 31. pedantic-negligent, 32. needed - useless, 33. active-passive, 34. direct-manipulative, 35. bold-shy, 36. poisonousacceptable. The modular software SPSS was used to evaluate the data obtained from the questionnaires.

\section{Results}

The resulting findings are presented in clear graphs and tables that reflect the various stages of statistical data processing, which we obtained through a questionnaire with implementation of the semantic differential method. 
Figure 1: Average perception profiles of non-commercial and commercial advertising

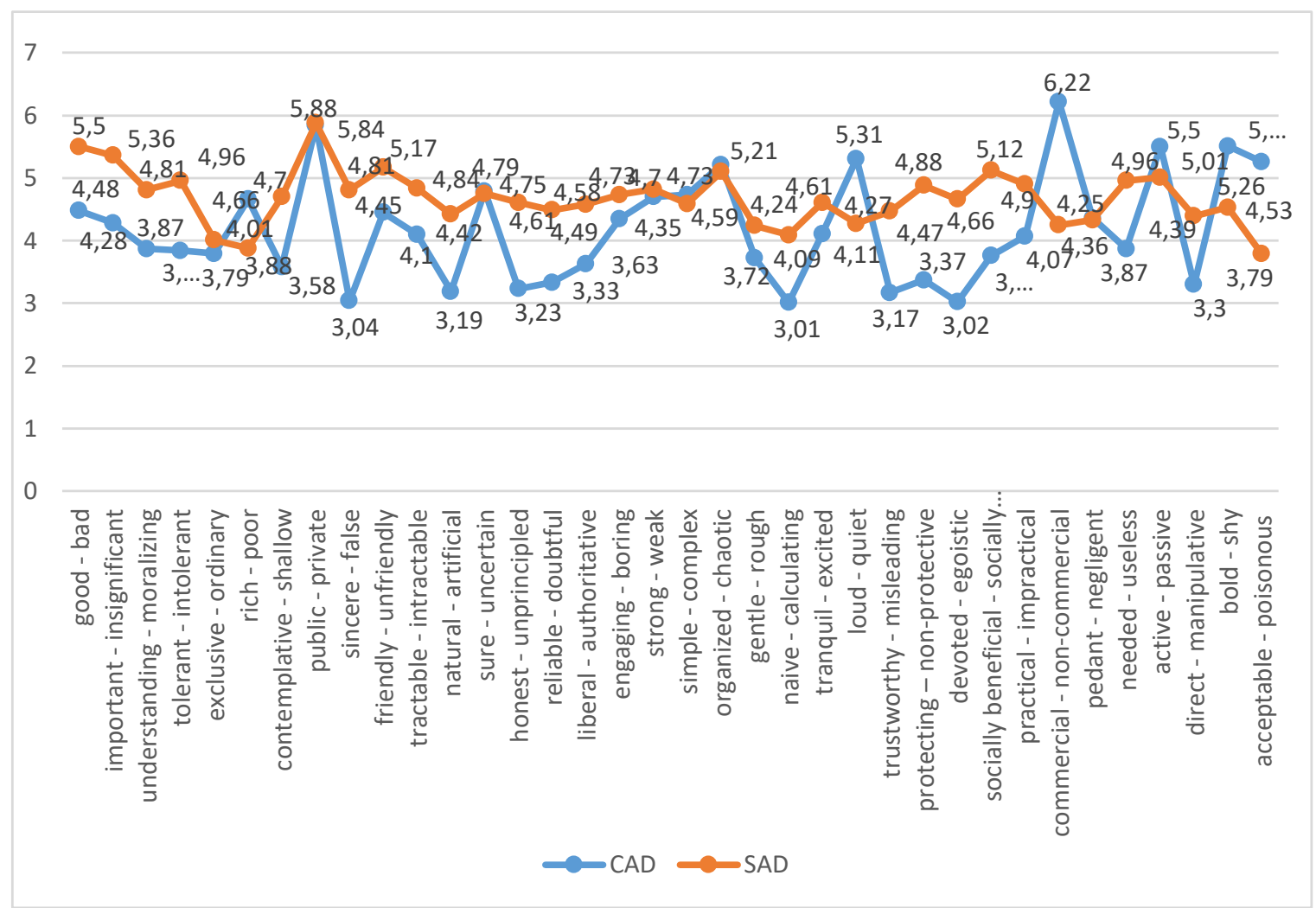

Source: original research

The resulting findings showed a significant similarity between the semantic profiles of the observed concepts of commercial and social advertising. Figure 1 presents a comparison of perception of the terms commercial advertising (CAD) and social advertising (SAD) in the whole research group of Generation Y respondents. As we can see in Graph 1, the investigated profiles are identical, the concepts are generally evaluated negatively, in the following order: social advertising $(\mathrm{AM}=4.68)$, commercial advertising $(\mathrm{AM}=4.18)$. The findings thus answer the research question RQ3. On closer inspection, however, we find some differences (Table 3). The results show that Generation Y perceives the terms commercial and social advertising mainly in negative connotations. In calculating the average values of the semantic differential for the term commercial advertising, the highest scores were achieved by the attributes: CAD30: non-commercial $(\mathrm{AM}=6.22), \mathrm{CAD} 8$ : private $(\mathrm{AM}=5.84), \mathrm{CAD} 35$ : shy $(\mathrm{AM}=5.51), \mathrm{CAD} 33$ : passive $(\mathrm{AM}=5.50), \mathrm{CAD} 24$ : quiet $(\mathrm{AM}=5.31), \mathrm{CAD} 36$ : annoying $(\mathrm{AM}=5.26), \mathrm{CAD} 20$ : chaotic $(A M=5.21)$, CAD19: difficult $(A M=4.73)$, CAD13: uncertain $(A M=4.79), C A D 18$ : weak $(A M=4.70)$. Based on the above, it can be concluded that the research question RQ1 is answered. In the calculation of the average values of the semantic differential for the term social advertising, the highest scores were achieved by the attributes: SAD8: private $(A M=5.88)$, SAD1: bad $(A M=5.50)$, SAD2: insignificant $(A M=5.36)$, SAD10: hostile $(A M=5.17)$, SAD28: socially unhelpful $(A M=5.12)$, SAD20: chaotic $(A M=5.10)$, SAD33: passive $(A M$ = 5.01), SAD4: intolerant $(A M=4.96)$, SAD32: unnecessary $(A M=4.96)$, SAD29: impractical $(A M=4.90)$. This thus confirms the answer to the established research question RQ2. 
Perception of commercial and social advertising

by generation $Y$ in the Czech Republic

Authors: Ivana Bulanda, Zdenka Kádeková,

Ingrida Košičiarová, Vladimír Vavrečka

Table 3: Average perception profiles of commercial and social advertising

\begin{tabular}{|c|c|c|c|c|c|}
\hline & \multirow[b]{2}{*}{ Adjectives } & \multirow{2}{*}{$\begin{array}{l}\text { CAD } \\
\text { AM }\end{array}$} & \multicolumn{3}{|c|}{ SAD } \\
\hline & & & SD & $\mathbf{A M}$ & SD \\
\hline 1. & good - bad & 4.48 & 1.560 & 5.5 & 1.322 \\
\hline 2. & important - insignificant & 4.28 & 1.602 & 5.36 & 1.467 \\
\hline 3. & understanding - moralizing & 3.87 & 1.509 & 4.81 & 1.612 \\
\hline 4. & tolerant - intolerant & 3.84 & 1.412 & 4.96 & 1.428 \\
\hline 5 & exclusive - ordinary & 3.79 & 1.811 & 4.01 & 1.547 \\
\hline 6. & rich - poor & 4.66 & 1.512 & 3.88 & 1.249 \\
\hline 7. & contemplative - shallow & 3.58 & 1.799 & 4.7 & 1.567 \\
\hline 8. & public - private & 5.84 & 1.606 & 5.88 & 1.225 \\
\hline 9. & sincere - false & 3.04 & 1.663 & 4.81 & 1.600 \\
\hline 10. & friendly - unfriendly & 4.45 & 1.553 & 5.17 & 1.231 \\
\hline 11. & tractable - intractable & 4.1 & 1.501 & 4.84 & 1.376 \\
\hline 12. & natural - artificial & 3.19 & 1.762 & 4.42 & 1.603 \\
\hline 13. & sure - uncertain & 4.79 & 1.754 & 4.75 & 1.388 \\
\hline 14. & honest - unprincipled & 3.23 & 1.483 & 4.61 & 1.543 \\
\hline 15. & reliable - doubtful & 3.33 & 1.577 & 4.49 & 1.554 \\
\hline 16. & liberal - authoritative & 3.63 & 1.509 & 4.58 & 1.423 \\
\hline 17. & engaging - boring & 4.35 & 1.822 & 4.73 & 1.543 \\
\hline 18. & strong - weak & 4.7 & 1.599 & 4.82 & 1.527 \\
\hline 19. & simple - complex & 4.73 & 1.462 & 4.59 & 1.429 \\
\hline 20. & organized - chaotic & 5.21 & 1.493 & 5.1 & 1.474 \\
\hline 21. & gentle - rough & 3.72 & 1.319 & 4.24 & 1.505 \\
\hline 22. & naive - calculating & 3.01 & 1.573 & 4.09 & 1.443 \\
\hline 23. & tranquil - excited & 4.11 & 1.476 & 4.61 & 1.385 \\
\hline 24. & loud - quiet & 5.31 & 1.454 & 4.27 & 1.556 \\
\hline 25. & trustworthy - misleading & 3.17 & 1.627 & 4.47 & 1.726 \\
\hline 26. & protecting - non-protective & 3.37 & 1.535 & 4.88 & 1.451 \\
\hline 27. & devoted - egoistic & 3.02 & 1.363 & 4.66 & 1.665 \\
\hline 28. & socially beneficial - socially unworthy & 3.76 & 1.712 & 5.12 & 1.760 \\
\hline 29. & practical - impractical & 4.07 & 1.565 & 4.9 & 1.467 \\
\hline 30. & commercial - non-commercial & 6.22 & 1.382 & 4.25 & 2.181 \\
\hline 31. & pedant - negligent & 4.36 & 1.367 & 4.33 & 1.288 \\
\hline 32. & needed - useless & 3.87 & 1.733 & 4.96 & 1.814 \\
\hline 33. & active - passive & 5.5 & 1.592 & 5.01 & 1.648 \\
\hline 34. & direct - manipulative & 3.3 & 2.149 & 4.39 & 1.639 \\
\hline 35. & bold - shy & 5.51 & 1.330 & 4.53 & 1.314 \\
\hline 36. & acceptable - poisonous & 5.26 & 1.567 & 3.79 & 2.027 \\
\hline Total & & 4.18 & 1.58 & 4.68 & 1.53 \\
\hline
\end{tabular}

Source: own research

By comparing the average perception profiles of the terms commercial advertising and social advertising in the whole examined set of Generation Y members, we did not observe occurrence of significantly significant differences in score of the semantic differential scales by means of a t-test. In view of the above, the answer to the research question RQ3 can be formulated. 
Figure 2: Correlations between the terms commercial and social advertising

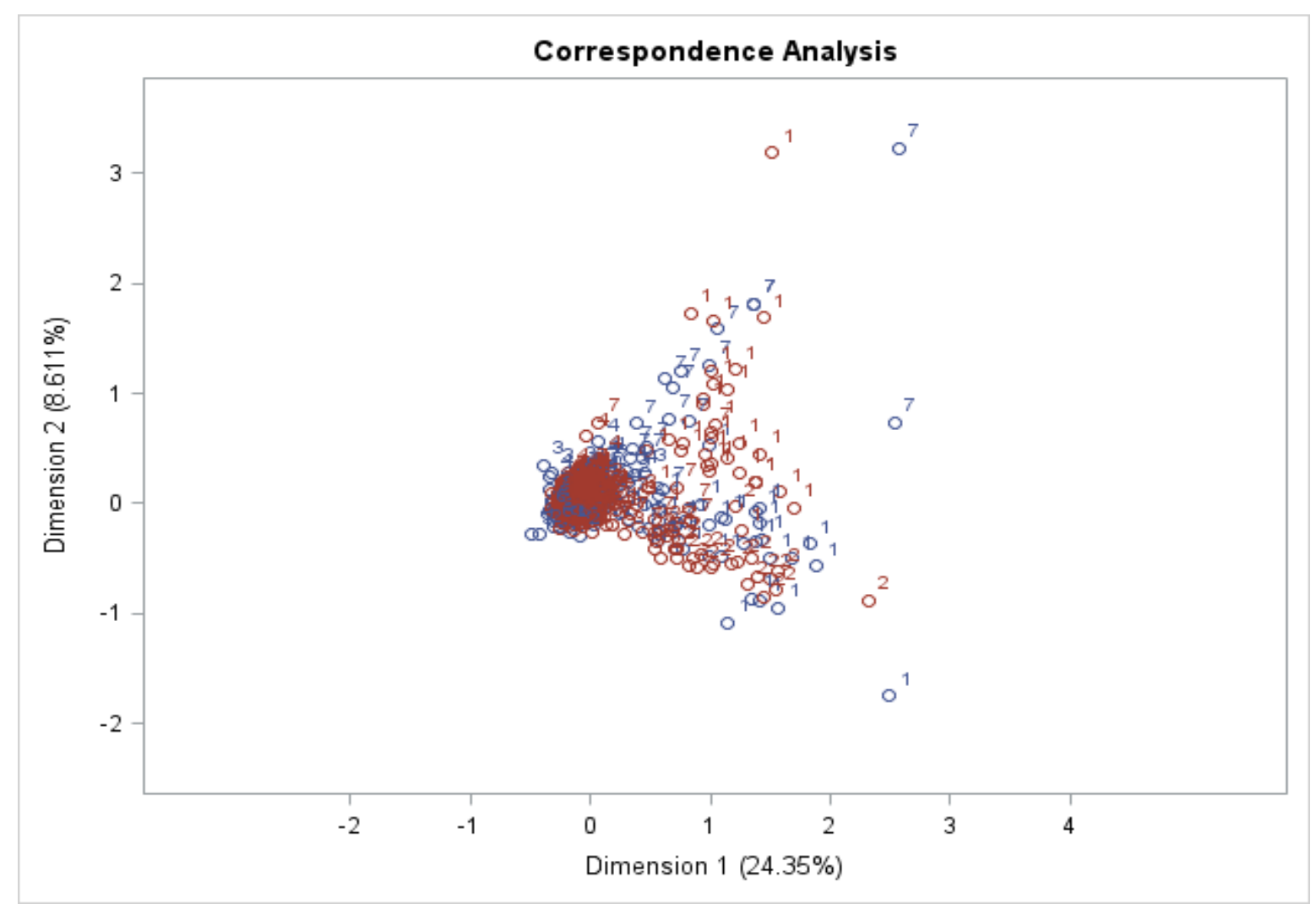

Source: original research-output of SAS 9.4

To determine the relationship between perception of the terms commercial and social advertising in the examined set of Generation Y members, we applied the Pearson correlation coefficient (Fig.2). Using it, we determined the tightness of the linear dependence between the variables. The correlation coefficient can take values from $\langle-1,1\rangle$. The correlation values in the individual items were from the specified interval (Table 4). This means that there is an interdependence between perception of the terms commercial and social advertising, which confirms our hypothesis.

\section{Discussion}

Research focusing on comparison of perception of the terms commercial and social advertising with the given research tools has not been carried out before in the Czech environment. In the field of marketing communication, research focuses mainly on independent examination of perception of commercial/social advertising or the attitudes towards commercial/social advertising in the spectrum of individual customer segments. The present study changes this by presenting partial outputs of the broadly conceived research "Value Orientation of Customer Segments in the Czech Republic" (GA/2019/13). The main goal of the study was to explore subjective perception of the terms commercial and social advertising in the Generation Y customer segment in the Czech Republic. In terms of setting the main goal, we formulated three research questions (RQ1, RQ2, RQ3) and one hypothesis $(\mathrm{H})$. The research group consisted of one hundred respondents, of which $52 \%$ were women $(\mathrm{N}=52)$ and $48 \%$ men $(\mathrm{N}=48)$. The average age of the whole research group was 37.93 years. Sixty-four respondents completed tertiary education and thirty-six respondents completed secondary education. This suggests that for Generation Y, education is the key to success. Its members are 
Perception of commercial and social advertising

by generation $Y$ in the Czech Republic Authors: Ivana Bulanda, Zdenka Kádeková, Ingrida Košičiarová, Vladimír Vavrečka

very pragmatic and rational, with a strong career orientation. As J. L. Hurst and L. K. Good point out, Generation $\mathrm{Y}$ tends to be exposed to intellectual challenges and achieving a prestigious degree plays an important role. These points underline the fact that Generation $\mathrm{Y}$ is much more educated than the previous generations; its members therefore recognize and value higher education as one of the essential factors in achieving job success. The resulting findings showed that the examined set perceives the concepts of commercial and social advertising in negative connotations; it is assumed that this is related to their negative attitude towards advertising in general. In addition, M. Cambal and E. Vaskovicova Zibrinova (2011) point out that Generation Y grew up surrounded by advertising and therefore does not trust it. Other research findings reported by R. Iyer et al. (2016) mention that Millennials perceive advertising as "manipulative, untrue and in some cases irritating". Generation Y has an overall negative attitude towards advertising, especially in terms of its credibility. Their most common attitude is cynicism. This may be due to the generally growing feeling of oversaturation of advertising in the media, in public and digital space (Bulanda and Vavrecka, 2019). This is also reflected in the environment of the Czech Republic, as reflected in the results of the research Czechs and Advertising 2020. The research line has been carried out regularly since 1993 and has long monitored how advertising is perceived by the Czech society. The 2020 research was commissioned by the Czech Marketing Company (ČMS), POPAI CE, and the Czech Association for Branded Products (ČSZV). It was carried out by the ppm factum research agency. Attitudes towards the role of advertising in Czech society remain ambivalent. Part of the population is aware of the importance of advertising for the economy and the media, but also sees its negative effects. At the same time, however, they express a negative opinion on the manipulative function of advertising. Compared to the findings from 2019, there was an increase in most positive attributes perceived, i.e., advertising belongs to modern life, is therefore an essential part of the economy and helps us in making choices. At the same time, there has been a marked decline in the notion that it promotes unnecessary consumption. Most people are overwhelmed by advertising on commercial television and the internet, while the overload of advertising on social networks is growing continuously. Advertising should have the main attributes of being true, understandable, non-violent, and trustworthy (ČMS, 2020). No significant differences in perception of the terms commercial and social advertising were noted in the research of the examined Generation Y group. At the same time, we found an interdependence between the perception of the terms commercial and social advertising. An interesting fact is the finding that despite the significant differences between the two forms of advertising, the ability to distinguish between them in Generation $\mathrm{Y}$ is small. An example is the paradox where the examined group predominantly assigned the attribute "non-commercial" to commercial advertising. The lack of distinction between commercial and social advertising could be due to both types of advertising using similar communication and persuasion mechanisms. As several authors point out, both types of advertising use the same symbols, characters, and meanings, i.e., the means of expression by which the central information (its content) is conveyed from the sender to the recipient. However, the audience's experience with them is quite different, in the case of social advertising - more real.

\section{Conclusion}

In general, perception is a term that refers to collection of information in the form of stimuli from the environment through the senses and their transformation through the relevant parts of the central nervous system into the higher psyche (especially the consciousness and the subconscious). An important aspect of the psychology of marketing communication is the so- 
called sensory perception and its components (visual perception, auditory perception, olfactory perception, taste perception, tactile perception) (Sedik et al., 2019). Each instance of perception is complemented by subjective factors; perception is a process associated with past experience. It is a complex process involving attitudes, interests, values, etc. (Juraskova et al., 2012). In the context of commercial and social advertising, this means that the individual creates an internal psychological picture of the message that is contained in both types of advertising. Marketing management and its commercial and social advertising first go through a process of sensory perception. followed by cognitive perception (Bulanda and Vavrecka, 2019a). The main purpose of the present paper was to report on the trends in marketing management concerning perception of the terms commercial and social advertising in the Generation Y customer segment in the Czech Republic. The resulting findings showed that the examined group perceived the concepts of commercial and social advertising in predominantly negative connotations. This negative perception can be influenced by the oversaturation of advertising in both public and digital space, or the so-called advertising smog. At the same time, the results pointed to an ambiguity in distinction between the terms commercial and social advertising and an existing correlation between the terms in question. This may be because both types of advertising, despite their specificity, use similar communication mechanisms and persuasive techniques. Also, from the point of view of customer segments, there is a certain crisis of attention, which can cause blurring of boundaries in the perception of attributes of the central message of commercial and social advertising. From the perspective of further scientific research, in would appear worthwhile to examine whether there are significant differences in perception of these concepts within marketing management in customer segments based on gender. It will be equally important and beneficial to examine the differences in individual generational cohorts as well as generational segments with their subsequent comparison.

\section{References}

Acar, A. B. (2014). do intrinsic and extrinsic motivation factors differ for generation X and generation Y? International Journal of Business and Social Science, 5(5), 12-20.

Bakos, L. (2014). Vhodnost' aplikácie súčasných štýlov riadenia na zamestnancov narodených po roku 1980. Výkonnost' podniku, 4(1),22-27.

Baran, M., \& Kłos, M. (2014). Pokolenie Y - prawdy i mity w kontekście zarządzania pokoleniami. Marketing $i$ Rynek, 11(2014), 923-929.

Barańska, M. (2011). Reklama i jej ograniczenia. Warszawa: Poltext.

Behrstock, E., \& Clifford, M. (2009). Leading Gen Y Teachers. Washington DC: National comprehehensive center for teacher quality.

Bolton, R. N. et al. (2013). Understanding generation Y and their use of social media: A review and research agenda. Journal of Service Management, 24(3), 245-267.

Bulanda, I., \& Vavrečka, V. (2019a). Perception of the non-commercial advertising of generation z from Slovakia. In A. L. da Silva, D. Tomic \& A. Grilec (Eds.), Economic and Social Development: "Sustainability from an Economic and Social Perspective" (pp. 455-465). Varazdin: Varazin Development and Entrepreneurship Agency.

Bulanda, I., \& Vavrečka, V. (2019b). Perception of commercial advertising by generation Y in intentions of transaction analysis. In A. Kusá, A. Zaušková \& Z. Bučková (Eds.), Marketing Identity - Offline Is the New Online. Conference Proceedings from the International Scientific Conference (pp. 454-470). Trnava: Faculty of Mass Media Communication, University of SS. Cyril and Methodius in Trnava.

Bulanda, I. (2017). Sociálna reklama v marketingovej komunikácii. In D. Hodinková (ed), Nové výzvy masmediálnej a marketingovej komunikácie (pp. 16-24). Nitra: Univerzita Konštantína Filozofa v Nitre.

Cambal, M., \& Vaskovicova Zibrinova, E. (2011). Generation Y in marketing. In B. KATALINIC (ed.): Annals of DAAAM for 2011 \& Proceedings of the 22nd International DAAAM Symposium (pp. 1571-1572). Vienna: DAAAM International.

ČMS (2020). Češi a reklama. <https://www.cms-cma.cz/wp-content/uploads/2020/02/TZ-\%C4\%8Ce\%C5\%A1ia-reklama-2020.pdf>. 
Perception of commercial and social advertising

by generation $Y$ in the Czech Republic

Authors: Ivana Bulanda, Zdenka Kádeková,

Ingrida Košičiarová, Vladimír Vavrečka

Doliński, D. (2010). Psychologiczne mechanizmy reklamy. Gdańsk: Gdańskie Wydawnictwo.

Dourado, A. (2017). The advertising in the sociological research in Portugal: Void or emerging domain? Revista Media \& Jornalismo. 8(1), 155-170.

Fabus, M., Lincenyi, M., \& Otrubcak, P. (2011). Marketing. Trenčín: TnUAD.

Faltanova, L. (1997). Reklama ako zdroj poznatkov o obchode v Bratislave (20. a 30. roky 20. storočia). Slovenský národopis, 45(3), 269-284.

Frankovsky, M., \& Birknerova, Z. (2016). Identifikovanie faktorov vnímania reklamy a faktorov vnímania manipulácie. Človek a spoločnost', 19(2), 56-67.

Gerus, O. (2014). Value aspects of modern Ukrainian advertising discourses. Media i Społeczeństwo, 4(4), 128134.

Herbold, J., \& Douma, B. (2013). Students' use of social media for job seeking. CPA Journal, 83(4), 68-71.

Herbus, I. (2016). Działania reklamowe - od komercji do kampanii społecznych. Zeszyty Naukowe Politechniki Częstochowskiej, 22(22), 93-100.

Horska, E., Petrilak, M., Sedik, P., \& Nagyova, L. (2020). Factors influencing the sale of local products through short supply chains: A case of family dairy farms in Slovakia. Sustainability, 12, 8499.

Iyer, R. et al. (2016). Perceptions of millennials' media attitudes and use: A comparison of u.s. and indian millennials. Marketing Management Journal, 26(2), 69-85.

Jankova, G. (2015). Adverfakt ako zrkadlo edukačnej a socializačnej funkcie médii. Nitra: Univerzita Konštantína Filozofa v Nitre.

Jankova, G., \& Runnova, K. (2017). Media culture and its impact on new forms of eating disorders. Episteme: Czasopismo Naukowo-Kulturalne, 12(34), 263-279.

Juraskova, O. et al. (2012). Velký slovni marketingových komunikací. Praha: Grada.

Kadekova, Z., \& Holiencinova, M. (2018). Influencer marketing as a modern phenomenoncreating a new frontier of virtual opportunities. Communication Today, 9(2), 90-105.

Kendrick, A., Fullerton, J. A., \& Kim, Y. J. (2013). Social responsibility in advertising: A marketing communications student perspective. Journal of Marketing Education. 35(2), 141-154.

Kim, N., \& Yu, S. Y. (2015). Effect of the characteristics of models of public service advertisements on public service behavior intension: Mediated effect on attitude of PSA. Indian Journal of Science and Technology, $8(8), 250-257$.

Kosiciarova, I., Kadekova, Z., Dzupina, M., Kubicova, L., \& Dvorak, M. (2020). Comparative analysis of private labels-private labels from the point of view of a millennial customer in Slovakia, Czech Republic and Hungary. Sustainability, 12, 9822.

Kosiciarova, I., Kadekova, Z., Kubicova, L., \& Rybanska, J. (2020). The consumer behavior of Slovak millennials in the segment of milk and dairy products within private labels. Slovak Journal of Food Sciences, 14, 798-806.

Koskova, M., \& Koprda, T. (2015). Vizuálna komunikácia v marketingovom prostředí. Nitra: UKF.

Koter, P., \& Armstrong, G. (2016). Principles of marketing. UK: Brunel University.

Kubicova, L., Kadekova, Z., Nagyova, L., \& Rovny, P. (2017). Slovak custumers demand for dairy products and milk: analysis of price and income relations. Marketing and Management of Innovations, (3), 165-176.

Lincenyi, M. (2013). Eploring media literacy among elementary schoopl pupils. Communication Today, 4(1), 7692.

Lonska, P. (2014). Knihovnické a informační služby ve veřejným knihovnách: Služby pro střední generaci čtenářů. ITlib, 2(2), 28-35.

Maison, D., \& Wasilewski, P. (2008). Propaganda dobrych serc, czyli rzecz o reklamie społecznej. Kraków: Agencja Wasilewski.

Matuszewska, A. (2013). Oddziaływanie reklam społecznych a system wartości jej odbiorców. Polityki Europejskie, Finanse i Marketing, 58(9), 318-327.

Mikulas, P., \& Svetlik, J. (2016). Execution of advertising and celebrity endorsement. Communication Today, 7(1), 92-103.

Nureeva, M. R. (2015). Comparative analysis of public service advertising regulation in Russian Federation and European countries. Journal of Institutional Studies, 7(1), 112-137.

Nagyova, L. et al. (2018). Marketing II. Nitra: Slovenská pol’nohospodárska univerzita.

Nagyova, L., Lencesova, J., Kosiciarova, I., \& Rybanska, J. (2019). Testing emotional and visual reactions to selected ads of the absolut company. In A. Kusá, A. Zaušková \& Z. Bučková (Eds.), Marketing Identity Offline Is the New Online. Conference Proceedings from the International Scientific Conference (pp. 223-255).

Polakevicova, I., Szabova, E., \& Kamenska, T. (2014). Prieskum závislosti medzi finančnými možnost'ami študentov generácie Y a nakupovaním na zl’avových portáloch. Forum Statisticum Slovacum, 10(6), 143-147.

Rybanska, J., Kosiciarova, I., \& Nagyova, L. (2019). Reklama a jej vplyv na vedomé a podvedomé spotrebitel'ské správanie na trhu potravín. Ostrava, Czech Republic: Key Publishing. 
Rybanska, J., Nagyova, L., \& Kosiciarova, I. (2015). Personality of consumer as a predictor of irrational consumer behaviour under the influence of sensorial stimuli. Proceedings of ICABR 2015. X. International Conference on Applied Business Research (pp. 888-896).

Sandikci, O. (2011). Shock tactics in advertising and implications for citizen-consumer. International Journal of Humanities and Social Science, 1(18), 42-50.

Smutka, L., Rovny, P., Pulkrabek, J., \& Horska, E. (2016). Zahraničný obchod s cukrom (HS1701) a cukor obsahujúcimi produktami (HS17) - komparácia Českej republiky so Slovenskom v priebehu posledných dvoch dekád. Listy Cukrovarnické a Řepařské, 132(7-8), 234-240

Svetlik, J. (2011). Czech and Slovak cultural dimensions and advertising. Communication Today, 2(2), 52-65.

Svetlik, J. (2018). Marketing cesta k trhu. Praha: VŠPP a. s.

Sedik, P., Horska, E., Skowron-Grabowska, B., \& Illes, Cs. B. (2018). Generation marketing in strategic marketing management: case study of honey market. Polish Journal of Management Studies, 18(1), 326-337.

Sedik, P., Knazovicka, V., Horska, E., \& Kacaniova, M. (2018). Consumer sensory evaluation of honey across age cohorts in Slovakia. Potravinarstvo Slovak Journal of Food Sciences, 12(1), 673-679.

Sedik, P., Tkac, F., \& Predanocyova, K. (2019). Consumer perception of cocoa-enriched honey: Young segment in Slovakia. Economics Management Inovace, 11(3), 71-80.

Szwajca, D. (2015). Determinants of the effectiveness of social advertising impact. Journal of Knowledge Society. $3(2), 1-9$.

Vopalenska, E. (2011). Informácie a emócie v kontexte mediálnej, osobitne reklamnej komunikácie. In P. Horňák \& E. Vopálenská (Eds.), Marketingová komunikácia a médiá: Zborník vedeckých štúdii (pp. 123-149). Bratislava: Book \& Book.

Vysekalova, J. et al. (2012). Psychologie reklamy. Praha: Grada.

Walotek-Ściańska, K. (2010). W'́siecie reklamy i reklamożerców. Bielsko-Biała: Wyższa Szkoła Administracji. Yagerova, J. (2012). Produktivní vztahy. 57 strategii pro upevňování obchodních kontakti̊. Olomouc: Anag.

Zelinsky, M., Bulanda, I., \& Teplanova, K. (2018). Perception of social advertising by university students in Slovakia and Africa. Analýza a Výskum v Marketingovej Komunikácii, 6(1), 16-26.

Zelinsky, M., \& Bulanda, I. (2019). Rozważania o związkach estetyki i reklamy. Zeszyty Naukowe Wyższej Szkoty Humanitas. Zarzadzanie, 2(2), 239-247.

Zelinsky, M., \& Bulanda, I. (2019). Body physicality as a key factor of media self presentation - body image in advertising. Zeszyty Naukowe Wyższej Szkoły Humanitas. Zarzadzanie, 4(4), 133-146. 